LEARNING FROM THE GLOBAL FINANCIAL CRISIS 
HIGH RELIABILITY AND CRISIS MANAGEMENT

Series Editors: Karlene H. Roberts and Ian I. Mitroff

SERIES TITLES

High Reliability Management: Operating on the Edge

By Emery Roe and Paul R. Schulman

2008

Dirty Rotten Strategies:

How We Trick Ourselves and Others into Solving the Wrong Problems Precisely

By Ian I. Mitroff and Abraham Silvers

2010

Swans, Swine, and Swindlers:

Coping with the Growing Threat of Mega-Crises and Mega-Messes

By Can M. Alpaslan and Ian I. Mitroff

2011 


\title{
LEARNING FROM THE GLOBAL FINANCIAL CRISIS
}

Creatively, Reliably, and Sustainably

\author{
Edited by \\ Paul Shrivastava \\ and Matt Statler
}

STANFORD BUSINESS BOOKS

An Imprint of Stanford University Press

Stanford, California 
Stanford University Press

Stanford, California

(C)2012 by the Board of Trustees of the Leland Stanford Junior University. All rights reserved.

No part of this book may be reproduced or transmitted in any form or by any means, electronic or mechanical, including photocopying and recording, or in any information storage or retrieval system without the prior written permission of Stanford University Press.

Special discounts for bulk quantities of Stanford Business Books are available to corporations, professional associations, and other organizations. For details and discount information, contact the special sales department of Stanford University Press. Tel: (650) 736-1782, Fax: (650) 736-1784

Printed in the United States of America on acid-free, archival-quality paper

Library of Congress Cataloging-in-Publication Data

Learning from the global financial crisis : creatively, reliably, and sustainably / edited by Paul Shrivastava and Matt Statler.

pages $\mathrm{cm}$

Includes bibliographical references and index.

ISBN 978-0-8047-7009-5 (alk. paper)

1. Global Financial Crisis, 2008-2009. 2. Crisis management. 3. Sustainable development. 4. Economic policy. I. Shrivastava, Paul, editor of compilation. II. Statler, Matthew, editor of compilation.

HB 37172008 .L43 2012

$330.9^{\prime} 0511-\mathrm{dc} 23$

2011030083

Typeset by Newgen in 10/14 Minion 
To the well-being of future generations 
